\title{
Potential of Regional Airport in České Budějovice
}

\author{
Lenka Ližbetinová ${ }^{1, *}$, Ladislav Bartuška $^{2}$, and Petr Průša ${ }^{3}$ \\ ${ }^{1}$ Faculty of Corporate Strategy, The Institute of Technology and Business in Ceske Budejovice, \\ Okružní 517/10, 37001 České Budějovice, Czech Republic \\ ${ }^{2}$ Faculty of Technology, The Institute of Technology and Business in Ceske Budejovice, Okružní \\ 517/10, 37001 České Budějovice, Czech Republic \\ ${ }^{3}$ Faculty of Transport Engineering, University of Pardubice, Studentská 95, 53210 Pardubice 2, \\ Czech Republic
}

\begin{abstract}
The objective of the contribution is to analyse the potential of the regional airport in České Budějovice after the modernization and obtaining the status of an international public airport in 2020 for the development of the region and inclusion in the category based on its importance. The South Bohemian region is one of the most visited regions in the Czech Republic. To be able to assess the potential considering its popularity among tourists, it is necessary to assess the need for connection of the airport to the transport infrastructure and thus improve its accessibility and comfort. The results published in the contribution are potential basis for further studies and planning of the territorial development of the region.
\end{abstract}

\section{Introduction}

The South Bohemian region is a region of the lowest population density and big differences in the population density. The border parts in Šumava are sparsely populated, as well as the Prachatice and Český Krumlov districts, which are the districts of the lowest population density in the Czech Republic (less than 38 per $\mathrm{km}^{2}$ ). The age structure in the region is similar to other regions of the Czech Republic. The average age of its inhabitants is 41.9, which is only 0.2 more than the average age in the Czech Republic. Similarly, the population ageing is also visible there. The biggest share of its inhabitants is at the age between 15-64 years. From this group, the target key segment of services provided by the Airport České Budějovice will be chosen. The South Bohemian region is the fifth region with the highest share of the people with university education in the Czech Republic. The important fact is, the many tourists visit historical centres of south Bohemian towns, numerous castles and chateaus and UNESCO world heritage sites located in the region [1]. České Budějovice is the most important town of the South Bohemian region, being situated almost in its centre. In the region, there is also a radially organised road and railway network, predominantly directed to the district town.

*Corresponding author: lizbetinova@,mail.vstecb.cz 
Regional airports in the Czech Republic play a significant role within the transport infrastructure. Currently, there are 91 airports (as of 16 September, 2018). The airports can be classified into several categories by the types of allowed movement of aircrafts. The airports in the Czech Republic have the potential of international, national or military movement. In addition, there is also scheduled, non-scheduled, mixed civil and military operation, general aviation or air ambulance service [2]. According to the Ministry of Transport [3] civil airports can be further classified into public and non-public airports. Table 1 shows the infrastructure of air transport between 2010 and 2018.

Table 1. Infrastructure of air transport in Czech Republic. Source: [3]

\begin{tabular}{|c|c|c|c|c|c|c|c|c|}
\hline Airport & 2010 & 2011 & 2012 & 2013 & 2014 & 2015 & 2016 & 2017 \\
\hline Public international & 7 & 6 & 6 & 6 & 6 & 6 & 6 & 6 \\
\hline Public national & 57 & 58 & 59 & 59 & 58 & 59 & 59 & 59 \\
\hline $\begin{array}{c}\text { Non-public } \\
\text { international }\end{array}$ & 6 & 5 & 5 & 5 & 3 & 3 & 3 & 3 \\
\hline Non-public national & 12 & 15 & 14 & 14 & 14 & 13 & 13 & 13 \\
\hline $\begin{array}{c}\text { Public national, but } \\
\text { non-public international }\end{array}$ & 9 & 7 & 7 & 7 & 10 & 10 & 10 & 10 \\
\hline
\end{tabular}

Airport České Budějovice, a. s. is authorized for operating public national airport and non-public international airport with an external border. Major competitors of Airport České Budějovice, a. s. are the airports in Karlovy Vary, Pardubice, Ostrava and Brno.

The abovementioned regional airports are included in the group of regional airports of higher importance, both national and international ones. The airports have proper navigation and runway systems, which allow them to provide complete services both for airlines and passengers. According to various studies, operating an airport has a positive effect on the development of a region [4-6]. In particular, the airport in České Budějovice has a high potential especially in tourism. Compared to the national average, the South Bohemian region has a significant number of accommodated persons. The number of the accommodated persons is currently the most accurate way to measure the attendance rate of the individual regions. According to the statistics of the Ministry for the Regional Development of the Czech Republic [7,8], the South Bohemian region is the fourth most visited region in terms of Czech residents, but most in terms of non-residents. The town of České Budějovice is not a final destination; however, it is an important railway and transport hub connected to the national communication network. A total of 2 international and 14 long-distance bus lines connect the town with important centres both in the Czech Republic and abroad. There are 5 railway lines passing through the town, both for the passenger and freight transport [7,9].

According to the statistics, there are annually about 150,000 visitors seeking for accommodation, out of which $64 \%$ are foreigners. However, there are also visitors coming for a one-day stay (without accommodation), which has not been included in the statistics. The highest numbers of tourists are from Germany, China, South Korea. There are also large number of tourists coming from the Netherlands, USA, Austria and Slovakia [8]. České Budějovice district is not an industrial area, but there is great potential for business trips and logistics of freight transport. There is, for example, the seat of Bosch factory, which is already using the services of the České Budějovice Airport [10]. 


\section{Methods}

The objective of the contribution is the analysis of the potential of the regional airport in České Budějovice after the completion of the modernization for the development of the region and inclusion in the category based on its importance. Since December 2017, the Airport České Budějovice has been undergoing the final phase of its modernization, with expected completion in 2019. Subsequently, the certification process for obtaining an international airline licence to operate an international public airport will take place. The licence is granted by the Civil Aviation Authority, and the statutory period for the entire certification process is from 6 months to one calendar year. Given to this, it can be assumed that in 2020, the airport will be able to operate international public service. The modernization includes the construction of a terminal for handling passengers, equipping the airport with radio navigation and navigation lightning, extension of the check-in area, construction of passengers car park and necessary facilities in order to ensure operation of air services [10].

The contribution is focused on the evaluation of the possible potential of the airport in terms of its ongoing modernization. For data collection, the information and documentation of the Ministry of Transport and Communication of the Czech Republic, information on planning and construction of transport infrastructure and more available information on the web related to the issue analysed [11]. As research methods, analysis and synthesis were used. The results published in the contribution can serve as a background for other studies and planned territorial development of the region.

\subsection{Analysis of strategic documents}

In addition to the modernization of the Airport České Budějovice, for its smooth operation, a quality transport infrastructure is necessary in order to ensure its accessibility within the region as well as its connection to the national and international transport network. Integrated plan of territorial development 2014-2020 [12] deals with construction of the E49 (Federal Republic of Germany - Pilsen - České Budějovice - Austria) and E 55 (Prague - České Budějovice - Austria) and the first-class roads are crucial for ensuring the basic transport accessibility. Completion of the D3 motorway on the Prague - Tábor České Budějovice - Dolní Třebonín route is supposed to help connect the town (or the district) to the European and national transport network. In the railway transport as in the basic part of the regional transport system, there are currently projects for development of ŽD4 and ŽD5 corridors with the aim of preparing the conditions for increasing the route capacity and its parameters for the Pilsen - Strakonice - České Budějovice - České Velenice - Czech Republic border (-Vienna), and Veselí nad Lužnicí - Třeboň - České Velenice - Czech Republic border (Vienna) [13, 14]. The program of the South Bohemian region development 2014-2020 [15, 16] in the v Priority Axis 2 deals with the transport mainly in terms improving the connection to the infrastructure in relation to the planned reconstruction of the Airport České Budějovice. Furthermore, emphasis is put on improving and optimizing the internal transport links and logistics in the region; at the same time ensuring the sustainable, quality connection to the technical infrastructure network corresponding with the region needs [15].

The concept of air transport for the period 2015-2020 [17] is based on three strategic documents of the European Commission: Europe 2020 - Strategy for smart and sustainable growth promoting inclusion, A Roadmap for moving to a competitive low carbon economy in 2050, and White Paper on transport. These documents are focused primarily on the issues of climate improvement and energy efficiency. The concept presents the results of the analysis within the Strategy for regional development, where, based on the territory 
typology, districts, among which České Budějovice is included, with a possible need for air transport services. According to this concept, the South Bohemian region is comparable with other Czech region with Class III operation airports [17], which includes "operation without scheduled air services enabling operation of charter flights and operation of private aircraft" (which is of great importance for investors and management of large companies, and increases the potential for regional development). In case of fulfilling other necessary conditions, the Airport České Budějovice has a potential of being included in the Class II operation airport category.

The document presents the design part, where the emphasis is put also on the development of regional airports, especially by creating environment adequate for their development, taking into account the possibilities of the given transportation market. In order to improve the transport serviceability of the given region, it is recommended to focus on finding balanced and adequate network combining national and international operation [18]. The trend of air transport development determined by the document directly entails the need for completion of the Airport České Budějovice, as well as the infrastructure in its surroundings. The concept puts emphasis on the following key points [17]:

- Protection of inhabited areas: the concept emphasizes that it is desirable that planes on the circuit do not fly over the inhabited areas of Homole, Nové Homole, Litvínovice and Planá (exceptions are allowed only in case of being properly announced and approved events). The airport can be used only by the airplanes equipped with air-to-ground radio transmitter.

- Ensuring air traffic safety: Just as important is ensuring the air traffic safety in terms of ensuring a properly functioning, smooth and safe operation of the Airport České Budějovice, which is obliged to prepare its own safety management systems. Equipping the airport with the navigation technology and technology for air traffic control will also contribute to ensuring air traffic safety. This will be the main topic of the second stage of the Airport České Budějovice modernization.

- Environmental protection: the greatest attention must be paid to noise and emissions. For this purpose, in addition to the national and EU legislation, ICAO standards and recommended practices based on the Convention on International Civil Aviation are used. Generally, emphasis is put on using alternative energy resources as well as on using air transport mainly for long-distance journeys.

- Equality of Rights and Opportunities: this includes the need to respect the rights of both passengers and air carriers, that is, no air carrier should be penalized. As for passengers, their rights and obligations are laid down in the Montreal Convention (Convention for the Unification of Certain Rules for International Carriage by Air).

- Civil-military cooperation: the concept emphasizes the necessity of maintaining civilmilitary cooperation, especially the possibility to enable using the airport for military purposes. This is also supported by the fact that the Airport České Budějovice is a former military airport, which means that there are still many facilities that the army could use in the future.

\subsection{Evaluation of transport infrastructure in view of Airport České Budějovice needs}

For the needs of the Airports, the connection to the regional communication network as well as to the national most important communications is necessary [18]. Currently, České Budějovice is the only district town in the Czech Republic without adequate connection to the national highway [19]. Another problem is the lack of by-pass roads, where the transit traffic burdens the town centre. For the Airport České Budějovice, another problem is I/3 road in Planá, where the highest traffic intensity was detected within measuring the 
intensity of entries from České Budějovice. The situation [20] has been actively solved since 2015, when the construction of the individual sections of D3 (Veselí nad Lužnicí Bošilec, Bošilec - Ševětín and Borek - Úsilné) was launched. In 2017, construction of a Ševětín - Borek section was started. Construction of the by-pass of České Budějovice (Úsilné - Hodějovice and Hodějovice - Třebonín) will be started soon, with a planned completion in 2022. By 2019, beginning of construction of the sections from Třebonín to the Austrian border is expected, with a planned completion in September 2022. The section 0308C Veselí nad Lužnicí - Bošilec $(5.1 \mathrm{~km})$ serves to increase the capacity of the I/3 road, constructed in advance as a half of the planned highway. It was put into operation in October 2017. In 2017, R4 Skalka - II/118 was also put into operation. It is about a $4.5 \mathrm{~km}$ section, which will take the transit traffic from Dubenec [13].

Basic transport accessibility of Č. Budějovice is ensured by international roads: E49 (Federal Republic of Germany - Pilsen - Č. Budějovice - Austria) and E55 (Prague - С̆.

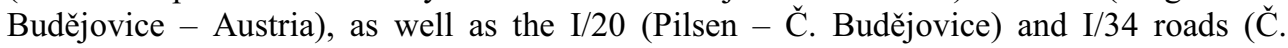
Budějovice - Jindřichův Hradec - Pelhřimov - Humpolec - connection to the D1 Prague highway - Brno) and I/3 (Prague - Č. Budějovice - state border with Austria [19].

\subsection{Connection of Airport České Budějovice to local infrastructure}

Currently, the connection of the airport to the $\mathrm{I} / 3 \mathrm{road}$ in the form of interchange is not convenient. It is a blind section with an increased accident rate. Also, there is a problematic access to the airport, where service road passes the non-maintained area owned by the Army of the Czech Republic. These problems could be removed by implementation of the project proposal prepared in 2013 on the basis of the South Bohemian region call [20]. This is to improve the connection of the Airport České Budějovice to the existing transport infrastructure of the I/3 road (prospectively II/603 for the D3 motorway operation). The study deals with two alternatives of improving the connection of the Airport České Budějovice to the $I / 3$ road by means of moving the connection to the $I / 3$ in the form of a circular intersection [21].

Railway and bus stations are located at the same place, about $1 \mathrm{~km}$ east of the town centre (Přemysl Otakar II. square). This transport terminal is connected with the airport by the existing I/3 and Mánesova roads (southern part of the town ring road). The distance from the future airport terminal is about $6 \mathrm{~km}$ [22]. The Airport České Budějovice is located about $4 \mathrm{~km}$ southwest of the České Budějovice centre, and is connected to the I/3 road (České Budějovice - Kaplice - Linec), which is a part of the European route E55 (Prague - České Budějovice - Linec), in the area belonging to the municipalities of Planá and Homole. The current traffic load data are from 2005. On the I/3 road between České Budějovice and Planá, there pass 23024 vehicles per 24 hours, 5120 of them being heavy vehicles [17]. The outlook for 2020 after the completion of the communication structure (including the D3 motorway) shows a decline to 16818 vehicles per 24 hours, 2263 of them being the heavy vehicles.

The area of the Airport České Budějovice is connected to the regional railway route České Budějovice - Český Krumlov - Kájov by its own siding from Boršov nad Vltavou. The siding is operational, and it is used mainly for freight transport for several industrial sites on the siding [23].

\section{Conclusion}

After finishing the modernization in 2020, the Airport České Budějovice has a potential of gaining the certificate of the international public airport. However, its effective use for the development of tourism, region as such and improving the logistics for the existing 
industries in the region suppose construction of quality transport infrastructure, that will make the airport more accessible for the passengers. The airport has also a potential for being included into the Class II operation airport category. Within this category, it is "air transport service corresponding to the TEN-T global network, which is characterized by connection with only several important European airports" [17]. At the same time, the airport must correspond to one of the three alternatives in terms of the distance to the nearest airport with a higher potential, where the distance is greater than:

- Approx. $100 \mathrm{~km}$ by motorway or double-track line, with a line speed not higher than $120 \mathrm{~km} / \mathrm{h}$,

- $130 \mathrm{~km}$ by a double-track line, with a line speed not higher than $160 \mathrm{~km} / \mathrm{h}$,

- $200 \mathrm{~km}$ by a high-speed line, line speed higher than $250 \mathrm{~km} / \mathrm{h}$.

Due to the sufficient distance from the capital as well as the prospective completion of the planned infrastructures, this condition could be fulfilled in the future. The concept recommends to ensure regular air service from Prague, but only in the case of completion and operation of the D3 and D4 motorways and the $4^{\text {th }}$ transit corridor (with the planned transport speed up to $160 \mathrm{~km} / \mathrm{h}$ ). This is conditioned by ensuring further investment in its development, including the possibility of the services provided and the possibility of using the airport even in bad weather conditions.

A major prerequisite for connecting the South Bohemian region and České Budějovice to European and national transport network within the multimodal corridor M1 is completion of the D3 on the Prague - Tábor - České Budějovice - Dolní Třebonín route and the 65 - R3 on the Dolní Třebonín - Kaplice - Dolní Dvořiště - state border route, which would enable the connection of the South Bohemian region to Austrian motorway network in the direction of Linz (expressway S10 - motorway A7) and the completion of the transit railway corridor (TŽK). The planned completion of this infrastructure, along with the location of České Budějovice, increases the potential of České Budějovice Airport for being included in the Class II operation airport category.

For the Airport České Budějovice, the completion of the D3 motorway is of strategic importance in terms of both public passenger and freight transport. Its completion and the existence of the airport increase the attractiveness of the region for investors. In terms of regional development, this situation influences the use of the airport. An advantage is also the existing siding, which could be used both for freight and passengers transport connection of the airport with the railway network.

At present, it is possible to use the facilities in the airport area, such as the logistics centre, flying club, extraordinary events, as well as transport for the management of large companies residing in the South Bohemian region. Obtaining the status of the airport for international public transport will have a positive effect in the form of increasing the accessibility of the region both for tourists and business clients, connection of České Budějovice to the international air corridor, increasing the attractiveness of the region for investors, congresses and other activities of professional character (which require the accessibility of the place of the event by air). A secondary impact would be the improvement of the region's image and thus also more labour opportunities [24, 25]. On the other hand, similarly as in other areas, this status has also negative impacts [26] on the environment and thus the deterioration in the living conditions of the people living in the vicinity of the airport (noise, cutting trees, night lightning, smog, heavier traffic on the roads to the airport).

This contribution was created within the solution of the Czech research project LTC17040 of the INTER-EXCELLENCE program, the INTER-COST subprogram. 


\section{References}

1. ČSÚ, Time series region [online]. [citate 2018-10-07]. Available at: https://www.czso.cz/csu/xc/casove_rady (2018)

2. AERONAUTICAL INFORMATION SERVICE, Airport and heliport overview [online]. [citation 2018-10-10]. Available at: http://lis.rlp.cz/ais_data/www_main_control/frm_cz_aip.htm (2018)

3. Ministry of Transport, Airport Information in the Czech Republic [online]. [citate 2018-10-10]. Available at: http://www.mdcr.cz/cs/Letecka_doprava/letiste/info.htm (2018)

4. P. Bujok, et al. Strategy of local and regional development of industrial cities Katowice and Ostrava with a focus on tourism. 16th International Multidisciplinary Scientific GeoConference SGEM 2016. 5, 1, 987-994. (2016)

5. M. Červinka, T. Tykva, The relation between air transport and selected aspects of the regional economy. Scientific Papers of the University of Pardubice - Series D. 18, 24, 31-42 (2012)

6. J. Lizbetin, O. Stopka, Proposal of a Roundabout Solution within a Particular Traffic Operation, OPEN ENGINEERING. 6, 1, 441-445 (2016)

7. Ministry of Transport, Transport Yearbook of the Czech Republic [online]. [citate 2018-10-17]. Available at: http://www.mdcr.cz/cs/Letecka_doprava/letiste/ (2018)

8. INCOMA Research s. r. o., Tourism Development Manual in the South Bohemian Region [online]. [citation 2018-10-07]. Available at: http://docplayer.cz/462856Manual-rozvoje-cestovniho-ruchu-v-jihoceskem-kraji.html (2007)

9. ČSÚ, Infrastructure of road transport in the Czech Republic and the region. Available at: https://www.czso.cz/csu/xc/infrastruktura-silnicni-dopravy-k-1-1-2018 (2018)

10. South Bohemian Airport České Budějovice, South Bohemian Airport České Budějovice $a$. $s$. [online]. [citate 2018-10-06]. Available at: http://www.airport-cb.cz/. (2016)

11. R. Kampf, O. Stopka, I. Kubasakova, V. Zitricky. Wmcaus 2016. DOI: 10.1016/j.proeng.2016.08.623 (2016)

12. KP projekt s. r. o., Integrated plan for development of the territory of České Budějovice [online]. [citation 2018-10-08]. Available at: http://www.mmr.cz/cs/Microsites/PSUR/Vyzva-c-2/ITI-a-IPRU/Statutarni-mestoCeske-Budejovice. (2014)

13. Czech motorways. Motorway. [online]. [citate 2018-10-16]. Available at: http://www.ceskedalnice.cz/. (2018)

14. Jikord, Rail transport to $\check{C} B$ airport. Available at: http://www.jikord.cz/webdata/JIKORD/jr/zeleznicni/doprava-letiste-06-2016.pdf (2018)

15. South Bohemian Region, Development Program of the South Bohemian Region 20142020 [online]. [citate 2018-10-08]. Available at: http://www.krajjihocesky.cz/1598/program_rozvoje_jihoceskeho_kraje_2014_8211_2020.htm. (2014)

16. Statutory City of České Budějovice, Strategic Plan of the City of České Budějovice 2008-2013 [online]. [citate 2018-10-08]. Available at: http://www.cbudejovice.cz/SiteCollectionDocuments/SPM_CB_verze_1582008FINALPOSEAhodn oceni_bezpríloh-0260.pdf (2008)

17. Ministry of Transport. Concept of air transport for the period 2015-2020. [Online] [Citate 10. 10 2018.] Available at: www.mdcr.cz (2018) 
18. O. Stopka, R. Kampf. Transport, 33, p. 280-290. DOI:10.3846/16484142.2016.1174882 (2018)

19. Road and Motorway Directorate of the Czech Republic, Motorway.[Online] [citate 11. 10 2018.] Available at: https://www.rsd.cz. (2018)

20. Ministry of Transport, Air Transport. [Online] [citate 11. 10 2018.] Available at: athttps://www.mdcr.cz/Uzitecne-odkazy/Letecka-doprava. (2018)

21. M. Weiszer, G. Fedorko, V. Molnar. CLC 2013: Conference: Carpathian Logistics Congress Proceedings, p. 330-335 (Cracow, 2014)

22. M. Telecký, J. Čejka, M. Guchenko. Logi. 9, p. 105-113 DOI: https://doi.org/10.2478/logi-2018-0012 (2018)

23. B. Abramovic, V. Zitricky, P. Mesko. Logi. 8, p. 1-10 DOI: https://doi.org/10.1515/logi-2017-0001 (2017)

24. M. Hitka, Z. Zavadska, D. Jelacic, Z. Balazova, Qualitative Indicators of Company Employee Satisfaction and Their Development in a Particular Period of Time. Drvna Industrija. 66, 3, 235-239 (2015)

25. M. Hitka, Z. Balazova, Comparison of Motivation Level of Service Sector Employees in The Regions of Slovakia and Austria, 2nd Global conference on business, economics, management and tourism, Book Series: Procedia Economics and Finance 23, 348-355 DOI: 10.1016/S2212-5671(15)00393-7 (2015)

26. K. Prušková, V. Nývlt, Issue of Building Information Modelling Implementation into the Czech Republic's Legislation using the Level of Development, Conference Series: Materials Science and Engineering 245, 8 article no. 082026 (2017) 